\title{
Translating Humour - A Didactic Perspective
}

\section{Gabriella KOVÁCS}

\author{
Sapientia Hungarian University of Transylvania (Cluj-Napoca, Romania) \\ Department of Applied Linguistics, Târgu-Mureş \\ kovacs_gabriella@ms.sapientia.ro
}

\begin{abstract}
Humour has various faces and forms, deriving from double meanings, situations, wordplay, often with hidden or obvious cultural references. It may also be subjective; the same things may seem humorous for some people and not funny at all for others. Probably most translators would agree that translating humour is definitely a very challenging task, especially when it is strictly related to the language itself or to a certain culture or community. However, there are certain forms of humour, especially situational or anecdotal, which focus on universal aspects or elements of human life, and therefore may be understood and considered as funny by people from different cultures. In this study, we discuss some theories, principles, recommended techniques and strategies related to translating jokes, wordplay, and humorous idioms which in our opinion may be included in the translator-training curriculum. We also examine the strategies and techniques used by a group of translator trainees in their second year of studies in translating humour from English into Hungarian, focusing on the difficulties they encountered, in order to assess their needs and include more practice and useful tips in the training process.
\end{abstract}

Keywords: humour, jokes, wordplay, idioms, translation, translator training

\section{Humour and translating humour}

Translating humour can be challenging even for seasoned translators, so it may be helpful if future translators and interpreters get a taste of it during the course of their training process. In the first part of our study, we focus on some theories, principles, recommended techniques and strategies related to translating jokes, wordplay, and humorous idioms which we believe may be included in the translator-training curriculum.

The difficulties of translating humour are frequently discussed in the literature. One of the problems may be that humour in its various forms - joke, wordplay, 
pun, idiom - is significantly defined by culture and language. In an article about translating humour in literary works, Venuti approaches target texts as relatively autonomous products, domesticized adaptations of the source language texts, reflecting more the target culture and language but also preserving its relation to the source text. He points out that certain losses and gains always occur in the process of translation. We may always observe "a loss of the foreign text at various levels: a loss of form and meaning, syntax and lexicon, sound and meter, allusion and intertextuality" (2002: 7). Martínez-Sierra (2006) and Jankowska (2009) also note that loss in the translation of humour can occur both in a quantitative and a qualitative sense. Studying jokes, they both found that, regardless of language pair and translation method, the target text is less humorous than the source text, which may result from having fewer humorous elements but also from the fact that the humorous elements are less humorous. Losses, however, may be compensated with other humorous elements placed elsewhere in the text (Klaudy 2014).

On the other hand, there may also be gain in translation, both on the linguistic and cultural level, "because translating is radically recontextualizing, actually exorbitant in its creation of another context" (Venuti 2002: 7). Primarily in literary translations, the linguistic and cultural gain often exceeds the source text and has significance mainly for the target language reader, conjuring elements of the receiving culture, its values and traditions. The formal and semantic dimensions of the source text are altered. Venuti calls these effects "domestic 'reminder' in a translation because they exceed the communication of a univocal meaning and reflect the linguistic and cultural conditions of the receptors" (2002: 8).

The success of translating humour can be relative because of the subjectivity of what individuals may or may not find humorous. It also depends on the genre as certain forms of humour, especially situational or anecdotal, focusing on universal aspects of human life, considered equally funny by people from different cultures, are usually more easily translatable than culture- and language-specific wordplays, puns, or idioms. However, a translator should bear in mind that the transmission of the humorous effect ought to be considered a primary factor in the success of humour translation, and, in agreement with Attardo, we should consider the text whose perlocutionary goal is to be perceived as humorous to be humorous because "the essence of a humorous text, its raison d'être is that of being perceived as funny, and that is reflected in the text itself" (Attardo 2001: 33).

\subsection{Translating jokes, wordplay, and/or puns}

A broad definition of joke is given in the Merriam-Webster dictionary: "something said or done to provoke laughter" or "a brief oral narrative with a climactic humorous twist". ${ }^{1}$ Jokes usually consist of a build-up, or set-up, followed by the punch line. The

1 https://www.merriam-webster.com/dictionary/joke 
build-up is usually a narrative, while the punch line is the final portion of the text, which is in incongruity with the set-up, producing a humorous effect (Attardo 2001).

Jokes can be isolated units, or they may be inserted in longer texts. They are defined by the cultural and social contexts and situations in which they are negotiated. Therefore, according to Popa (2005: 49), in order to translate them adequately, translators must bear in mind the complexity of the phenomenon and focus on the transfer of the linguistic, situational, and cultural content of the joke into the target language while respecting the skopos of the translation.

Low claims that translating "a joke in a way that cannot elicit a smile is a betrayal, no matter how semantically accurate it may seem” (Low 2011: 69), and he proposes eight strategies to translate them:

1) Delivery followed by preparation means that punch lines are translated first, possibly making them even "tighter and punchier". This is followed by the work on the preparation part, adding explanations of implied details, if necessary (Low 2011: 69).

2) Compensation in kind means that translators can use other forms of verbal humour: for instance, if they cannot translate an anagram, they "may use a pun or a spoonerism or a silly mixed metaphor. Any statement can be made amusing just by adding an exaggeration, a malapropism or a simile as silly as a sausage" (Low 2011: 69).

3) Compensation in place means inserting a funny, witty allusion in the next sentence.

4) Dilution refers to translating a certain number of puns with less.

5) Explicitation means that in some cases a one-liner can be better translated in the form of a two-liner. If in the source text we have "Consumerism has made invention the mother of necessity", it may be translated in two clauses, as "Consumerism has reversed the old proverb and made invention the mother of necessity", which is definitely less humorous but still more than nothing (Low 2011: 69).

6) Exaggeration is exemplified with the translation of a French joke about Nicolas Sarkozy, a "Super-Sarko joke", in the case of which instead of translating it in English as "Nicholas Sarkozy can tag the sound barrier", it was amended by Low to "Sarkozy can leap over the sound barrier and tag both sides" (Low 2011: 69).

7) Signalling means to mention the existence of a joke instead of translating it. For example, an interpreter who does not have enough time to think about how to translate a joke can at least say: “'That's very droll in Chinese' or 'Here the speaker would like you to laugh'” (Low 2011: 69).

8) Substitution refers to the use of a humorous text with different meaning but equally funny. Low finds this solution acceptable, but he does not consider it a form of translation (Low 2011: 70).

The issue of untranslatability in the domain of translating humour most often occurs related to wordplays because of their accentuated language specificity. As 
the term wordplay itself suggests, it is a play with words, with their pronunciation and meaning. In order to translate wordplays or puns, it is important to understand their features.

The various perceptions and attempts to define this concept point to its complexity. There is no universally accepted definition, but there are several important characteristics that scholars agree upon. Delabastita gives a concise definition of wordplay or pun, stating that it is "the general name for the various textual phenomena in which structural features of the language(s) are exploited in order to bring about a communicatively significant confrontation of two (or more) linguistic structures with more or less similar forms and more or less different meanings" (Delabastita 1996: 128). Different meanings may be activated by similar or sometimes identical forms such as in homonyms, homophones, homographs, or paronyms, and these structures may occur in the same part of a text (vertically) or one after another (horizontally).

Related to form, Giorgadze claims that "wordplay can be expressed in ambiguous verbal wit, orthographic peculiarities, sounds and forms of the words, in breaking the grammar rules and other linguistic factors" and also highlights the importance of context in actualizing the wordplay, or pun, "as its pragmatic role (mainly humorous, satirical, sarcastic, etc.) is fulfilled and actualized in a specific context" (Giorgadze 2014: 271).

Regarding the definition of pun, it seems that scholars have not reached a consensus either. It is often regarded as a synonym of wordplay; for example, Delabastita (1996) uses the terms wordplay and pun interchangeably, as synonyms. Others define pun as a type of wordplay or joke. According to Low, puns are "those kinds of wordplay that exploit the ambiguities of words or phrases. Since the majority of puns have a humorous intent, they form a subset of 'jokes'", and he highlights that puns may cause extra difficulties for translators because "they use the specific features of a particular language" (Low 2011: 60).

The translatability of wordplays or puns raises many questions, and it is definitely a challenge for translators. Ballard points out that translation is an exercise in reading and construction of meaning, and therefore, in the early stages of translator training, students should be shown how and why incorrect readings may occur. Therefore, the paradigm of ambiguity should be explored, which can result from identity of sounds and spellings in homonyms, identity of sounds in homophones, partial similarity of sounds and spellings in paronyms, or a signifier with different meanings in polysemy (Ballard 1996: 334-335). Because of the involved ambiguity, any of these phenomena may become the source of humour.

According to Benő (2016: 61), translating wordplays requires in a way the preservation of the source language form, which contradicts the habitual translation procedures that involve a disengagement and abstraction from the source language forms by expressing the meaning of the original, source language signs with the 
means of the target language. If the intention was to preserve the source language form, most wordplays would be untranslatable. And yet, in everyday translation practice, they are translated. Translation is more than an exchange of words, replacement of source language lexical units with target language words. Literal, word-for-word translation may lead to poor, incomprehensible results, and this is especially relevant when translating puns.

Low proposes six tools for translating puns: 1) replicating the source text pun; 2) achieving dynamic equivalence by creating a new pun, verbally connected with the source text; 3) using "a different humorous device, particularly where the humour is more important than the meaning”; 4) compensating in place by ensuring a wordplay near the pun; 5) giving an expanded translation, an explanation of the pun, which usually leads to the loss of humorous effect; 6) ignoring the pun, giving a partial translation of the phrase, without wordplay (Low 2011: 67).

The first five tools imply that creativity is essential. In a study about the didactics of translation focusing on the issues of wordplay, Ballard (1996) concludes the following: "Creativity, we should teach our students, can be far more effective than accuracy in the translation of wordplay. Wordplay is an area par excellence where word-for-word translation usually misses the point. What is more relevant than semantic meaning in many instances of wordplay is the stylistic device itself, the relationship between words" (Ballard 1996: 344).

\subsection{Translating funny idioms}

We discussed the definition and typology of idioms and the difficulties of their translation in two previous studies (Kovács 2016a, b). We concluded that idioms are an essential part of any language, but because of their large variety and culture and language specificity there is no complete agreement regarding their definition or typology. A concise definition is given by the Merriam-Webster dictionary: "an expression in the usage of a language that is peculiar to itself either in having a meaning that cannot be derived from the conjoined meanings of its elements (such as up in the air for 'undecided') or in its grammatically atypical use of words (such as give way)". ${ }^{2}$ There are different types of idioms, and there might be differences regarding the ways they are understood and translated. Lexical items referring to objects, living creatures, humans, phenomena, concepts, or various culture-specific elements can all be part of what we call idioms. In order to translate idioms from the source language into the target language, the translator should first recognize the idiom in the text, understand its meaning, and then choose the most appropriate strategy, taking into consideration the peculiarities, function, culture specificity, and the semantic and structural unpredictability of these expressions.

2 https://www.merriam-webster.com/dictionary/idiom 
We also discussed and exemplified Baker's (1992) five proposed strategies for translating idioms (Kovács 2016a, b). Here we focus on idioms considered humorous, ${ }^{3}$ and therefore we give examples of English-Hungarian translations for the first three of Baker's strategies:

1) Using an idiom of similar meaning and form means to use an idiom in the target language that has approximately the same meaning as the source language idiom and contains equivalent lexical items (e.g. cat got your tongue - a cica elvitte a nyelvedet).

2) Using an idiom of similar meaning but dissimilar form means to find an idiom in the target language with a similar meaning to that of the source language idiom but containing different lexical items (e.g. kick the bucket - feldobja a talpát).

3) Translation by paraphrase can be considered the most common way of translating idioms when it is inappropriate to use idiomatic expressions in the target text because of differences in stylistic preferences or when no match can be found in the target language (e.g. out of the blue - a semmiból). However, when translating funny idioms, the humorous effect can be easily lost in a paraphrase.

4) Translation by omission is the case when idioms can be omitted from the target text mainly because they cannot be easily paraphrased, they do not have a close match in the target language, or because of stylistic considerations. If we omit a funny idiom from the target text, not only the meaning but also the humorous effect is lost.

5) The strategy of compensation "means that one may either omit or play down a feature such as idiomaticity at the point where it occurs in the source text and introduce it elsewhere in the target text" (Baker 1992: 78).

In line with Baker, we believe that the most fortunate case is when the translator manages to find an idiom with a similar meaning in the target language, and this may be especially relevant when translating humorous idioms.

\subsection{Attardo's General Theory of Verbal Humour}

Attardo $(2001$, 2002) developed a General Theory of Verbal Humour (GTVH) relevant and applicable to all types of humorous texts, which may be used by translators to evaluate how much the translated text differs from the source text. According to this theory, the manifestations of verbal humour can be analysed based on six parameters (Knowledge Resource):

(1) Language ( $L A)$ "contains all the information necessary for the verbalization of a text. It is responsible for the actual wording of the text and for the placement of the functional elements that constitute it" (Attardo 2002: 176). It is important to understand that the same message or information can be expressed in various ways (with synonyms or different grammatical constructions). Therefore, jokes or

3 https://www.lifehack.org/articles/lifestyle/15-funny-english-idioms-you-may-not-know.html https://matadornetwork.com/pulse/10-funniest-idioms-people-learning-english/ 
humorous stories can be paraphrased, told and written in different ways, conveying the same meaning and effect. Ideally, when translating humour, only the level of language is changed, and the other Knowledge Resources remain intact.

(2) Narrative Strategy (NS) refers to the narrative organization of the text, which may be, for example, a dialogue, a simple narrative, or a riddle.

(3) Target (TA) is an optional parameter; it can be identified mainly in humorous texts that have a target or a butt, something or somebody that is being ridiculed. It is usually the name of individuals or groups that can be stereotyped.

(4) Situation (SI) involves that humorous texts or jokes are usually "about something”, and it includes the objects, participants, means, tasks, and activities of the humorous statement.

(5) Logical Mechanism (LM) refers to the resolution of incongruities; however, it is not necessarily present in all humorous texts as the resolution of the incongruity is optional in humour (for example, in humour based on absurd or nonsense). LMs can range from juxtapositions (e.g. Gobi Desert Canoe Club) to errors in reasoning (e.g. "Madonna does not have it, the Pope has it but doesn't use it, Bush has it short, and Gorbachev long. What is it? Answer: a last name.”) (Attardo 2002: 181).

(6) Script Opposition (SO) is present in every humorous manifestation, and it is considered the most abstract Knowledge Resource. For its presence, two conditions must be met: the text must be partially or fully compatible with two different scripts, and these two scripts are opposite in such a way that, at the same time, they partially or completely overlap in the given text. The opposition either dissolves at the end (e.g. jokes) or it does not (e.g. nonsense, absurd), but its presence is necessary in order to achieve a humorous effect (Attardo 2002: 181-182).

Based on the General Theory of Verbal Humour, Attardo proposes a minitheory of humour translation, offering practical advice for translators who may encounter humorous texts: "if possible, respect all six Knowledge Resources in your translation, but if necessary, let your translation differ at the lowest level necessary for your pragmatic purposes" (Attardo 2002: 183). He admits that it may be utopian to respect all of the Knowledge Resources, but if none of them is respected, then the outcome cannot be called a translation "and may be either the refusal or acknowledged failure of the translator to render the text in TL, or the creation of humour in TL that was not in SL, or failure of the translator to spot the joke in SL" (Attardo 2002: 184).

\section{Students' translations}

In this part, we aim to analyse some of the solutions which translator trainees chose while translating various types of humour - jokes, puns, and funny idioms - from English into Hungarian. For this assignment, the jokes, puns, and funny 
idioms were carefully selected in order to cover several types from these categories. The members of the target group (26 second-year students) study translation and interpreting at Sapientia Hungarian University of Transylvania, Faculty of Technical and Human Sciences Târgu-Mureş. The sample of this study is not large enough to draw general conclusions regarding the strategies of translating humour from English into Hungarian. We present a short qualitative analysis of our students' translations referring to some of the above mentioned theories and principles in order to obtain a better view of the difficulties our students encounter, assess their needs, and utilize our findings for curriculum development.

\subsection{Jokes, wordplays, and puns translated from English into Hungarian}

In order to illustrate and discuss our students' difficulties related to the translation of jokes, wordplays, or puns, we chose some examples of successful and unacceptable translations from their assignments.

Table 1. Translating a joke (1)

\begin{tabular}{|c|c|c|}
\hline Source text & $\begin{array}{l}\text { Example for successful } \\
\text { translation (Student 1) }\end{array}$ & $\begin{array}{l}\text { Example for unacceptable } \\
\text { translation (Student 2) }\end{array}$ \\
\hline $\begin{array}{l}\text { A linguistics professor } \\
\text { was lecturing his class } \\
\text { the other day. "In } \\
\text { English", he said, "a } \\
\text { double negative forms } \\
\text { a positive. However, in } \\
\text { some languages, such } \\
\text { as Russian, a double } \\
\text { negative remains a } \\
\text { negative. But there isn’t } \\
\text { a single language, not } \\
\text { one, in which a double } \\
\text { positive can express a } \\
\text { negative". } \\
\text { A voice from the back of } \\
\text { the room retorted, "Yeah, } \\
\text { right”. } 4\end{array}$ & $\begin{array}{l}\text { A minap egy } \\
\text { nyelvészprofesszor } \\
\text { magyarázta az } \\
\text { osztályának: } \\
\text { - Az angolban a } \\
\text { kettős tagadás állítást } \\
\text { eredményez. Viszont, } \\
\text { egyes nyelvekben, mint } \\
\text { például az oroszban, a } \\
\text { kettős tagadás tagadás } \\
\text { marad. De egyetlen } \\
\text { olyan nyelv sem létezik, } \\
\text { amelyben kettôs állítás } \\
\text { tagadást fejezne ki. } \\
\text { Egy hang beszólt a terem } \\
\text { hátsó részéből: } \\
\text { - Igen, persze. }\end{array}$ & $\begin{array}{l}\text { Egy lingvisztikai tanár } \\
\text { tanítás közben: } \\
\text { - Az angolban két negatív } \\
\text { egy pozitívat formál, de } \\
\text { más nyelvekben pl. orosz } \\
\text { két negatív negatív marad. } \\
\text { Nincs egy nyelv sem, } \\
\text { amelyikben két negatív } \\
\text { egy pozitívat hoz létre. } \\
\text { Egy hang hátulról: } \\
\text { - Hát tényleg. }\end{array}$ \\
\hline
\end{tabular}

If we examine the second student's unacceptable translation with the help of Attardo's GTVH, we can observe various losses regarding LA. In the first sentence, the student uses an expression which is incorrect and unacceptable in Hungarian: "lingvisztikai tanár" (linguistical teacher). He also omits the translation of the

4 https://www.myenglishpages.com/site_php_files/joke.php?t=514 
phrase "the other day", the conjunction "but" introducing the fourth sentence of the source text, and the verb "retorted" from the last sentence. He does not use the conventional terms from Hungarian linguistics for "negative" and "positive". And, finally, the total transformation of the last two words - the punch line - kills the joke in the target text. Regarding the NS, the student successfully followed the narrative organization of the source text. TA does not exist in this source text. Regarding the SI, most elements are present (the teaching situation, the characters - a teacher and the student who makes the comment from the back of the room). The student failed to convey the LM, the resolution of incongruity by mistranslating the punch line of the joke. In the source text, the final comment consists of two positives - "Yeah, right" - exposing the inaccuracy of the professor's reasoning, while in the target text the "voice from the back of the room" agrees with the professor, saying "Hát tényleg." (meaning "Well, of course.”). Regarding SO, the two opposing but overlapping scripts in this joke would be the professor being right or wrong. However, this opposition does not dissolve in the end because of the inaccurate translation of the last remark.

While the first student managed to respect all the existing five Knowledge Resources (LA, NS, SI, LM, and SO) in her translation, the second student failed to respect three of them (LA, LM, and SO). The following reasons can be detected regarding the second student's failure to translate the joke: he probably did not spot the humour in it, or, if he did, he could not convey it in the target language; he also had difficulties in finding acceptable equivalents for certain source language elements and used omission too often.

Table 2. Translating a joke (2)

\begin{tabular}{|c|c|c|c|}
\hline text & $\begin{array}{l}\text { Successful } \\
\text { translation }\end{array}$ & $\begin{array}{l}\text { Poor translation } \\
\text { (1) }\end{array}$ & $\begin{array}{l}\text { Poor translation } \\
(2)\end{array}$ \\
\hline $\begin{array}{l}\text { A teacher asked } \\
\text { a particularly } \\
\text { dull, lazy, and } \\
\text { objectionable pupil } \\
\text { if he was ignorant } \\
\text { or apathetic. } \\
\text { The pupil replied: } \\
\text { "I don't know, and } \\
\text { I don't care!"5 }\end{array}$ & $\begin{array}{l}\text { A tanár } \\
\text { megkérdezett egy } \\
\text { szembeötlően lassú } \\
\text { észjárású, lusta } \\
\text { és kifogásolható } \\
\text { magatartású diákot, } \\
\text { hogy ostoba vagy } \\
\text { fásult. } \\
\text { A diák azt } \\
\text { válaszolta: } \\
\text { - Nem tudom és } \\
\text { nem is érdekel. }\end{array}$ & $\begin{array}{l}\text { A tanár } \\
\text { megkérdezte egy } \\
\text { lusta, kifogásolható } \\
\text { diákját, hogy mi } \\
\text { lenne, ha nem } \\
\text { viselkedne ilyen } \\
\text { tudatlanul és } \\
\text { érzéketlenül. A } \\
\text { diák válaszolta: } \\
\text { - Nem tudom és } \\
\text { nem is érdekel. }\end{array}$ & $\begin{array}{l}\text { A tanár } \\
\text { megkérdezett } \\
\text { egy unott, lusta } \\
\text { diákot, hogy mi } \\
\text { lenne, ha tudatlan } \\
\text { és nemtörődöm } \\
\text { lenne. Erre azt } \\
\text { válaszolta a diák, } \\
\text { hogy nem tudja, de } \\
\text { nem is érdekli. }\end{array}$ \\
\hline
\end{tabular}

5 http://transpremium.com/a-few-of-the-most-hilarious-language-and-translator-jokes/ 
If we examine the two poor translations comparing them with the successful one with the help of Attardo's GTVH, we can observe various losses and errors regarding LA. The students who produced poor translations omitted one of the pupil's attributes - the first did not translate "dull”, while the second omitted "objectionable" and mistranslated "dull" as "unott" (bored). They also encountered difficulties in the translation of the second part of the first sentence: "if he was ignorant or apathetic". This is a simple reported question, but both of them translated it as a complex reported sentence containing a conditional sub-clause, altering it significantly on syntactic level, thus also changing its meaning: (1) "mi lenne, ha nem viselkedne ilyen tudatlanul és érzéketlenül" (what if he did not behave so ignorantly and insensitively); (2) "mi lenne, ha tudatlan és nemtörődöm lenne" (what if he were ignorant and careless). However, all the students who translated this joke rendered the punch line in acceptable forms. Regarding the NS, the students successfully followed the narrative organization of the source text. Regarding the SI, most elements are present (the characters - the teacher and the student). In the two poor translations, the students failed to convey the LM, the resolution of incongruity, because, even though they translated the punch line correctly, they failed to convey the build-up phase of the joke by altering the meaning of the second sentence. Regarding SO, the opposing but overlapping scripts in this joke would be that the pupil's answer proves one of the options given by the teacher to be true or none of them. This opposition does not dissolve in the end because of the inaccurate translation of the teacher's question.

The student who translated the joke successfully managed to respect all the existing five Knowledge Resources (LA, NS, SI, LM, and SO) in his translation, while the other two students failed to respect three of them (LA, LM, and SO). The following reason can be detected regarding these students' failure to translate the joke: they had difficulties in finding acceptable equivalents for certain source language structures, thus altering the meaning significantly.

Table 3. Translating a pun (1)

\begin{tabular}{|c|c|c|c|}
\hline Source text & $\begin{array}{l}\text { Successful } \\
\text { translation }\end{array}$ & $\begin{array}{l}\text { Poor translation } \\
(1)\end{array}$ & $\begin{array}{l}\text { Poor translation } \\
(2)\end{array}$ \\
\hline $\begin{array}{l}\text { "She (tearfully): } \\
\text { You said if I'd } \\
\text { marry you, } \\
\text { you'd be humbly } \\
\text { grateful. } \\
\text { He (sourly): Well, } \\
\text { what of it?" } \\
\text { She: "You are not; } \\
\text { you are grumbly } \\
\text { hateful." (Benô } \\
\text { 2016: 62) }\end{array}$ & $\begin{array}{l}\text { „Feleség: Azt } \\
\text { mondtad, ha } \\
\text { hozzád megyek, } \\
\text { készséges } \\
\text { férjuram leszel. } \\
\text { Férj (mogorván): } \\
\text { Na és mi lettem? } \\
\text { Feleség: Rémséges } \\
\text { kényuram.” (Benő } \\
\text { 2016: 62) }\end{array}$ & $\begin{array}{l}\text { A nő (könnyezve): } \\
\text { - Azt mondtad, ha } \\
\text { a feleséged leszek, } \\
\text { szerény és hálás } \\
\text { leszel. } \\
\text { A férfi (keserúen): } \\
\text { - S akkor mi? } \\
\text { - Nem lettél az. } \\
\text { Zsörtölödö és } \\
\text { utálatos vagy! }\end{array}$ & $\begin{array}{l}\text { Az asszony: } \\
\text { - Azt mondtad, ha } \\
\text { a feleséged leszek, } \\
\text { alázatosan hálás } \\
\text { leszel! } \\
\text { A férj, savanyúan: } \\
\text { - Na, és? } \\
\text { Az asszony: } \\
\text { - Nem vagy az, } \\
\text { szörnyen utálatos } \\
\text { vagy. }\end{array}$ \\
\hline
\end{tabular}


This text was chosen from an article about puns and translation by Attila Benő (2016). It is a wordplay which presents a sad and painful situation in a humorous light. When faced with an English wordplay, our translator trainees' first reaction would often be that it cannot be translated. None of them managed to translate this wordplay successfully. Eight of them did not translate it at all, while the others tried but failed to convey the humour resulting from combining words with similar forms but opposite meanings, mainly because the Hungarian equivalents of these words (humbly grumbly, grateful - hateful) are not formally similar: they do not rhyme, and they do not have the same number of syllables: humbly grateful - alázatosan/szerényen hálás; grumbly hateful - morgóan/zsörtölődően gyúlöletes/utálatos). The wordplay, which at first sight may seem untranslatable, was the result of linguistic creativity. This means, as Benő (2016) suggests, that the translator, like the author, should use creativity and find playful and witty expressions, taking advantage of the possibilities offered by the target language, as we can see in the example for successful translation. Obviously, this domesticizing process involves compromise, resulting in some loss, which, on the other hand, can be counterbalanced with linguistic and cultural gain. This can be observed in the example for successful translation, where, in order to preserve the wordplay as a source of humour, and also the message of the joke, the translator did not use the equivalents mentioned above but word pairs with different meaning (készséges - rémséges, férjuram - rémuram), forming the phrases készséges férjuram (my willing/attentive husband) - rémséges kényuram (my terrible oppressor/tyrant). Besides these, Benő (2016: 63) proposes two other alternatives: engedelmesen édes (obediently sweet/gentle) - rettenetesen rémes (horribly terrible/terribly horrible) or édesen hálás (sweetly grateful) - rémesen lármás (terribly noisy/boisterous).

The students' translations render the meaning of the source text correctly, but neither of them is humorous. Instead, both examples of poor translation highlight the sadness and bitterness of the situation.

Table 4. Translating a pun (2)

\begin{tabular}{lll}
\hline Source text & Successful translations & Unsuccessful translations \\
\hline Why does the teacher & Miért visel a tanár & Miért visel a tanár \\
wear sunglasses? Because & napszemüveget? Mert a & napszemüveget? Mert a \\
his students are so & diákjai annyira ragyogóak & diákjai annyira fényesek/ \\
bright. $^{6}$ & / sziporkázóak. & világosak / okosak. \\
\hline
\end{tabular}

The pun in this example is based on polysemy, the two meanings of the word bright (literal meaning: shining, glittering, sparkling; figurative meaning: clever, intelligent, smart). Twenty out of the 26 students managed to translate it successfully, using a Hungarian equivalent, which has the same literal and figurative meaning as the English word. Those who failed did not understand the joke and chose equivalents covering

6 https://explainthejoke.com/2019/01/25/brilliance/ 
only one of the two meanings, thus forming absurd answers (meaning: Because his students are so shining, glittering.), or they understood it but failed to choose an equivalent with the same literal and figurative meaning, thus giving answers which did not relate to the question (meaning: Because his students are so clever, intelligent.).

But not all puns are so easily translatable, as demonstrated in the following example.

Table 5. Translating a pun (3)

\begin{tabular}{lll}
\hline Source text & Translation (1) & Translation (2) \\
\hline “I was arrested at the & - A repülőtéren & - Letartóztattak a repülőtéren. \\
airport. Just because I & tartóztattak le. Csak & Csak azért, mert köszöntem \\
was greeting my cousin & azért, mert köszöntöm & Jack unokatestvéremnek! Pedig \\
Jack! All that I said & Jack unokatestvérem! & csak annyit mondtam, hogy „Hi \\
$\begin{array}{l}\text { was 'Hi Jack', but very } \\
\text { Coud.”7 }\end{array}$ & $\begin{array}{l}\text { Csak annyit mondtam, Jack”, de nagyon hangosan. } \\
\text { hogy „Hi Jack”, de }\end{array}$ & $\begin{array}{l}\text { (Ez angolul úgy is érthető, } \\
\text { nagyon hangosan. } \\
\text { mintha azt mondta volna, hogy } \\
\text { eltérítés.) }\end{array}$ \\
\hline
\end{tabular}

Here the humorous effect is based on the homophony between "Hi Jack" and the word hijack (to commandeer a flying airplane especially by coercing the pilot at gunpoint). ${ }^{8}$ As shown in the selected examples, our students applied mainly two strategies. 12 of them assumed that the target reader would know enough English to understand the joke even if the key element of the humorous effect was not translated. Even though it may work in some cases, this version cannot be accepted as a completed translation. The other 14 students used a strategy which can be considered an expanded translation (defined by Low 2011: 67), an explanation of the pun, which leads to the loss of the humorous effect, but their effort might trigger a polite smile.

When humour is the main purpose of a text, and we have to choose between sacrificing language play and making minor changes to the conceptual meaning, it is more advisable to preserve the language play by slightly changing the meaning than to produce an accurate but dry outcome.

\subsection{Funny idioms translated from English into Hungarian}

In this section, we propose to exemplify the applied strategies and the difficulties encountered by our group of 26 students when translating twenty funny English idioms ${ }^{9}$ into Hungarian. The students' choices were categorized into acceptable

7 http://iteslj.org/c/jokes-puns.html

8 https://www.merriam-webster.com/dictionary/hijack

9 The idioms were selected from the following sources: https://www.lifehack.org/articles/ lifestyle/15-funny-english-idioms-you-may-not-know.html; https://matadornetwork.com/ 
and unacceptable translations, and the acceptable ones were further divided into translations preserving and losing the humorous effect. The main strategies chosen were also examined. From Baker's five strategies, we could identify three: (1) using an idiom of approximately similar meaning and form, (2) using an idiom of similar meaning but dissimilar form, and (3) translation by paraphrase. We also identified (4) omission and (5) literal (word-for-word) translation, two options which in this case we cannot be accepted as productive strategies. Examples:

(1) The idiom all mouth and no trousers, meaning "full of boastful, arrogant, or shallow talk, usually by a male, who then cannot deliver on his claims", ${ }^{10}$ was translated successfully by the majority of the students:

Table 6. Translations of the idiom "all mouth and no trousers"

\begin{tabular}{|c|c|c|c|c|c|}
\hline $\begin{array}{l}\text { SL } \\
(\mathbf{E N})\end{array}$ & $\begin{array}{l}\text { Students' translation of } \\
\text { the idiom - TL (HU) }\end{array}$ & $\begin{array}{l}\text { Strategy } \\
(1 / 2 / 3 / 4 / 5)\end{array}$ & $\begin{array}{l}\text { Acceptable, } \\
\text { funny } \\
\text { translations/ } \\
\text { nr. of stud. }\end{array}$ & $\begin{array}{c}\text { Acceptable } \\
\text { but not funny } \\
\text { translations/ } \\
\text { nr. of stud. }\end{array}$ & $\begin{array}{l}\text { Unacceptable } \\
\text { translation/ } \\
\text { nr. of stud. }\end{array}$ \\
\hline \multirow{13}{*}{ 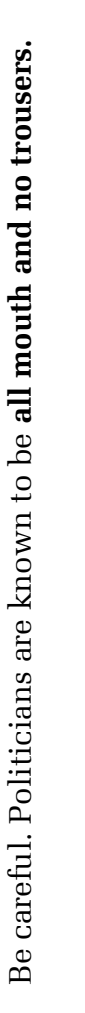 } & szájhős & 2 & 4 & & \\
\hline & szájkaratés & 2 & 2 & & \\
\hline & $\begin{array}{l}\text { lyukat beszélnek a } \\
\text { hasadba, de nem } \\
\text { tesznek semmit }\end{array}$ & $2 / 3$ & 1 & & \\
\hline & csak a szájuk jár & 2 & 9 & & \\
\hline & $\begin{array}{l}\text { politikusok ígéreteiből } \\
\text { lesz gazdag a szegényből }\end{array}$ & 3 & 1 & & \\
\hline & $\begin{array}{l}\text { hajlamosak arrogánsan } \\
\text { beszélni, de nem } \\
\text { csinálnak semmit }\end{array}$ & 3 & & & 1 \\
\hline & $\begin{array}{l}\text { politikusok ígéretei } \\
\text { nem teszik gazdaggá a } \\
\text { szegényt }\end{array}$ & 3 & & 1 & \\
\hline & $\begin{array}{l}\text { füt-fát megígérnek, } \\
\text { aztán sehol semmi }\end{array}$ & 2 & 1 & & \\
\hline & $\begin{array}{l}\text { sokat ígérnek, de } \\
\text { keveset tartanak be }\end{array}$ & 3 & & 1 & \\
\hline & $\begin{array}{l}\text { bort isznak s vizet } \\
\text { prédikálnak }\end{array}$ & 2 & 2 & & \\
\hline & $\begin{array}{l}\text { amelyik kutya ugat, nem } \\
\text { harap }\end{array}$ & 2 & & & 1 \\
\hline & $\begin{array}{l}\text { nagy a kotkodácsolás, } \\
\text { kicsi a tojás }\end{array}$ & 2 & 1 & & \\
\hline & $\begin{array}{l}\text { csak a szájukkal } \\
\text { merészek, tetteikkel } \\
\text { nem }\end{array}$ & 3 & & 1 & \\
\hline
\end{tabular}

pulse/10-funniest-idioms-people-learning-english/

10 https://idioms.thefreedictionary.com/all+mouth+and+no+trousers 
(2) The translation of the idiom hairy at the heel, meaning "dangerous or untrustworthy"11 proved to be the most difficult for our students.

Table 7. Translation of the idiom "hairy at the heel"

\begin{tabular}{|c|c|c|c|c|c|}
\hline $\begin{array}{l}\text { SL } \\
(\mathrm{EN})\end{array}$ & $\begin{array}{c}\text { Students' translations } \\
\text { - TL (HU) }\end{array}$ & $\begin{array}{l}\text { Strategy } \\
(1 / 2 / 3 / 4 / 5)\end{array}$ & $\begin{array}{l}\text { Acceptable, } \\
\text { funny } \\
\text { translations/ } \\
\text { nr. of stud. }\end{array}$ & $\begin{array}{c}\text { Acceptable } \\
\text { but not funny } \\
\text { translations/ } \\
\text { nr. of stud. }\end{array}$ & $\begin{array}{c}\text { Unacceptable } \\
\text { translation/ } \\
\text { nr. of stud. }\end{array}$ \\
\hline \multirow{2}{*}{$\sum_{\substack{3 \\
0}}^{3}$} & alvilági fickó & 3 & & 1 & \\
\hline & $\begin{array}{l}\text { agresszív tud lenni/ } \\
\text { kicsit agresszív }\end{array}$ & 3 & & 2 & \\
\hline 胥 & forrófejú & 2 & 1 & & \\
\hline \multirow{3}{*}{. } & ravasz, mint a róka & 2 & & & 2 \\
\hline & olyan, mint az időjárás & 2 & 1 & & \\
\hline & galád/szélhámos & 3 & & 1 & \\
\hline \multirow{2}{*}{ 雨 } & olyan, mint a jó idő & 2 & & & 2 \\
\hline & furcsa & 3 & & & 1 \\
\hline \multirow{2}{*}{$\begin{array}{ll}0 & 0 \\
0 & 0 \\
0 & 0 \\
0 & 0 \\
0 & 0 \\
0 & 0 \\
0 & 0\end{array}$} & pongyola & 3 & & & 1 \\
\hline & $\begin{array}{l}\text { kecskére nem bíznám a } \\
\text { káposztát }\end{array}$ & 2 & 1 & & \\
\hline \multirow{5}{*}{ 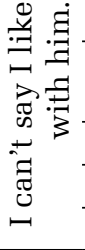 } & szôröstalpú & 2 & & & 4 \\
\hline & $\begin{array}{l}\text { megbízhatatlan, } \\
\text { veszélyes/kétes alak }\end{array}$ & 3 & & 3 & \\
\hline & fel van vágva a nyelve & 3 & 1 & & \\
\hline & - & 4 & & & 4 \\
\hline & szőrös a sarka & 5 & & & 1 \\
\hline
\end{tabular}

As we can see in the examples, in the translation of funny idioms, the main reasons for unacceptable translations were mainly misinterpretation of the SL idiom or failure to find an acceptable equivalent. In many cases, students managed to translate the idioms but failed to preserve their humorous effect. The most frequently chosen strategy was the attempt of using an idiom of similar meaning but dissimilar form, followed by paraphrasing, which contradicts Baker's (1996) and our own (Kovács 2016b) conclusion that paraphrasing would be the most frequently used strategy in the translation of idioms. The reason why students tried to use more often idioms in the target language in this particular assignment may be that they believed this way they had better chances to preserve the humorous effect. And, indeed, most successful translations were a result of using an idiom of similar meaning but dissimilar form (e.g. did a runner - olajra lépett; give him the cat's arse - lapátra teszi/pipa lesz/kiteszi a szürét; when pigs fly - sohanapján/majd ha piros hó esik/majd ha fagy; to chew the fat - hogy kibeszéljék a krumplit a földból;

11 https://www.usingenglish.com/reference/idioms/hairy+at+the+heel.html 
as cool as a cucumber - laza mint a biciklilánc; kick the bucket-feldobja a talpát; they're as dead as a doornail - kihaltak, mint a dínók; raining cats and dogs - esik, mintha dézsából öntenék).

In conclusion, we suggest that recognition and comprehension, creativity and flexibility may lead to successful translations when dealing with funny idioms in the translation process.

\section{Final notes}

In this study, we conducted an overview of some theories, principles, recommended techniques and strategies related to translating humour - jokes, wordplays, puns, and funny idioms. We believe they may be helpful in translator training, especially if they are combined with the analysis and explanation of examples from EnglishHungarian translations and sufficient practice.

In the assessment of the difficulties and problems that our students encounter in translating humour, we found that the main reasons why they often fail are the following: insufficient knowledge and understanding of source language (English) lexical and grammatical structures and lack of creativity and flexibility necessary for the translation of humour.

Even though translating humour may not be their priority in their work as future translators, we believe that working with humorous texts can be a helpful means in developing our students' language skills, creativity, openness, and problemsolving skills. Based on this study, a further step in our work will be granting more importance to humour translation in the curriculum. The study and evaluation of the designed and applied solutions in curriculum development may be the topic of a further study.

\section{References}

Attardo, Salvatore. 2001. Humorous Texts: A Semantic and Pragmatic Analysis. Berlin-New York: Mouton de Gruyter.

- 2002. Translation and humour. An approach based on the General Theory of Verbal Humour (GTVH). The Translator 8(2): 173-194.

Baker, Mona. 1992. In Other Words: A Coursebook on Translation. London-New York: Routledge.

Ballard, Michel. 1996. Wordplay and the didactics of translation. The Translator 2(2): 333-346.

Benő, Attila. 2016. Nyelvi játék és fordítás [Puns and translation]. Korunk 2016 (4): 61-66. 
Delabastita, Dirk. 1996. Introduction. In Dirk Delabastita (ed.), Wordplay and Translation: Essays on Punning and Translation. Special Issue of "The Translator" 2(2): 1-22.

Giorgadze, Meri. 2014. Linguistic features of pun, its typology and classification. European Scientific Journal. Special edition 2: 271-275.

https://www.researchgate.net/publication/327106368_linguistic_features_of_ pun_its_typology_and_classification (Last accessed: 24 May 2020).

Jankowska, Anna. 2009. Translating humour in dubbing and subtitling. Translation Journal 13(2): n.p. https://translationjournal.net/journal/48humor.htm (Last accessed: 24 May 2020).

Klaudy, Kinga. 2014. Bevezetés a fordítás gyakorlatába [Introduction to Translation Practice]. Budapest: Scholastica.

Kovács, Gabriella. 2016a. About the definition, classification, and translation strategies of idioms. Acta Universitatis Sapientiae, Philologica 8(3): 85-101.

- 2016b. An evergreen challenge for translators. The translation of idioms. Acta Universitatis Sapientiae, Philologica 8(2): 61-71.

Low, Peter Alan. 2011. Translating jokes and puns. Perspectives: Studies in Translatology 19(1): 59-70.

Martínez-Sierra, Juan José. 2006. Translating audiovisual humour. A case study. Perspectives: Studies in Translatology 13(4): 289-296.

Popa, Diana-Elena. 2005. Jokes and translation. Perspectives: Studies in Translatology 13(1): 48-57.

Venuti, Lawrence. 2002. Translating humour. Performance Research: A Journal of the Performing Arts 7(2): 6-16. 